\title{
Explorations in Dutch New Guinea: Discussion
}

Author(s): Thomas Holdich, A. F. R. Wollaston, Eric Marshall, H. A. Lorentz, W. R. OgilvieGrant, H. O. Forbes, Mackintosh Bell and C. G. Rawling Source: The Geographical Journal, Vol. 38, No. 3 (Sep., 1911), pp. 252-255

Published by: geographicalj Stable URL: http://www.jstor.org/stable/1779039

Accessed: 16-04-2016 07:40 UTC

Your use of the JSTOR archive indicates your acceptance of the Terms \& Conditions of Use, available at

http://about.jstor.org/terms

JSTOR is a not-for-profit service that helps scholars, researchers, and students discover, use, and build upon a wide range of content in a trusted digital archive. We use information technology and tools to increase productivity and facilitate new forms of scholarship. For more information about JSTOR, please contact support@jstor.org.

The Royal Geographical Society (with the Institute of British Geographers), Wiley are collaborating with JSTOR to digitize, preserve and extend access to The Geographical Journal 
in the mountains, and when encamped on the rivers to the cast and west; and Lieut. Cramer, the leader of the escort, the only European who had remained with us from the beginning to the end, who had filled a difficult rôle with such ability, tact, and success. Of the Gurkhas I must specially mention Mahesur, Jangbir, and Harkajit.

To sum up the final results of the expedition: large and valuable collections of birds, mammals, reptiles, butterflies and moths had been formed, together with botanical and ethnographical specimens; a new and unknown race of pygmies discovered, studied, measured, and photographed; a range of mountains, containing the greatest precipice in the world, together with 3000 square miles of country, surveyed and mapped, new snow-mountains found, and many great rivers explored; and a long stretch of coast-line surveyed. We had accomplished the longest crosscountry journey ever undertaken in Dutch New Guinea, i.e. eleven marches from the up.river camp, had proved the impossibility of the Mimika river as a line of advance to the Snows, and on the other hand the value of the great rivers to the east if the same goal is intended. From experience, and our heavy death-roll will bear me out, I have no hesitation in saying, firstly, that the land is an impossib!e one to any but a Papuan; and secondly, that, unless most carefully vicked, no native of the East Indies, with the exception of Dyaks from Borneo, are of the slightest value as carriers in South Dutch New Guinea.

Sir Thomas Holdich, Vice-President (before the paper): In the absence of our President, who I regret to say is not able to be here to-night, I have one short announcement to make to you, which J am sure will be received with great pleasure by all of you. The Duke of Connaught has kindly consented to accept the position of Honorary President of the Society.

To the great majority of the audience here to-night, Captain Rawling will be an old friend. But for the sake of the minority who may not know quite what Captain Rawling's claims as a practical geographer may be, I will tell you that he commenced his career in the wild and windy wastes of Western Tibet. That was his first call. From there he brought back to us, I think, some of the first, if not some of the best, of the scientific surveys of that most inhospitable country that we have ever had. On that first occasion he succeeded in mapping some 35,000 or 40,000 square miles of country which was absolutely new to us geographically. Shortly after that, you may remember, he joined that memorable expedition which was led by Sir Francis Younghusband (whose recent accident we so greatly deplore), and on that occasion, in company with Captain Ryder, he carried a survey along the long valley of the upper Brahmaputra till he reached the source of that river and of the Sutlej, and thence they returned to India by way of Gartok. He then also brought to us a memorable supply of fresh geography, for I think they covered something like 40,000 square miles of country on that occasion. Subsequently Captain Rawling was recalled to Gyantse in Tibet. Finally he was selected by the Geographical Society to represent this Society in the expedition in which he has been recently engaged to New Guinea. You will therefore understand that Captain Rawling as a geographer is about as good a man as any of us could appeal to if we wished 
to have a thorough knowledge of the subject in hand, and I will ask him at once to commence his lecture, which I know will be full of interest from first to last.

Sir Thomas Holdich (after the paper) : I am sure you will agree that New Guinea must be a country full of the most strenuous interest; interest which has been illustrated to you to-night by as remarkable a series of photographs as I think I have ever seen. I feel inclined, however, to envy Captain Rawling the pleasure he must have felt at finding himself face to face with a well-dressed audience. Judging from the photographs we have seen, I should say the beauty unadorned is not always adorned the most. I will ask Mr. Wollaston to speak to us if he will.

Mr. A. F. R. Wollaston: There is one thing in which I differ from Captain Rawling-and that is, he says Carstensz peak will never be climbed. I have studied that peak many times with field glasses, from a climbing point of view, perhaps fifty or sixty times, and I am fully convinced that there are on the south side at least two ways by which it might be climbed. At least one might reach the snow, and after the snow there is probably no difficulty at all in getting to the top. But I hope we may know more about it in time. Captain Rawling is very much to be congratulated on his most admirable lecture, and the description he has given us of the difficulties of climate and circumstance he had to contend with in order to produce this map we have seen and these most beautiful pictures.

Dr. Erio Marshall : This morning I asked Captain Rawling if he would leave anything for me to say, and he replied, "Well, you will know after the lecture," but he has covered the ground so completely that he has left very little. Those who have any experience of the conditions of travel in the great plains and wastes of the tropical or polar regions may at first sight be rather astonished at the comparatively small area traversed and explored by our expedition during fifteen months in New Guinea. When one looks at the physical features, and the great difficulty in providing a suitable transport, this can be better appreciated. The country yields nothing upon which a white man can subsist, and even the native, when removed from his own district and adjacent sago swamp, finds it quite impossible to live on the scanty food which the jungle provides. Wallaby, pig, and cassowary are to be found in the jungle, and our knowledge of the few procured by the natives during our stay in the country shows us that enough of these are not available to support life when dependent on animal food alone. The mountainous districts provide nothing; sago swamps cease at about 10 to 12 miles south of the mountains. The dense jungle and knife-edged ridges are destitute of game, and as one rises up the spurs and slopes of the mountains, the birds, at no time plentiful, become very scarce. It is therefore necessary for the traveller to carry every ounce of food with him, eking it out whenever possible with any game which may be procurable. The ordinary Javanese or Dutch East Indian coolie can only carry about 30 lbs., besides his own bedding-that is, that he can only carry food for himself for fifteen days. Therefore it comes to this, that fifteen days is the limit of a single advance, unless depotts have been established and supplies accumulated at suitable points. In addition to this, there are certain standard loads which have to be accounted for and do not diminish in weight, such as tents, flies, bedding, instruments and cooking utensils, so that, allowing that one has Dyak coolies, who can carry a slightly heavier load, the final advance is very restricted. In the polar regions (Antarctic) it is possible for three men to travel, independent of any supporting party, hauling their own equipment and supplies, for from three months to even 
four months, if relay work is undertaken. In the jungle and swamps of this part of New Guinea, three white men would require about thirty carriers for about fifteen days, and though you increase the number of coolies, you do not proportionately increase the length of travel, unless the coolies can be returned as their loads are consumed, and in order to do this many men must be employed in keeping the communication open, and they again must be fed. No expedition should stay in the country for more than nine months, for the climate saps the energies and strength of the white man, and even in this space of time it would be necessary to introduce fresh blood amongst the coolies. There should be no unnecessary delays in procuring these, so that from the time the expedition lands until it leaves, the work may go on without interruption.

An expedition should go in on the south coast, at the end of September or beginning of October, when it would have the best eight to nine months, and these none too good, of the year to carry out its work, for during the other three months it is impossible to make any satisfactory progress, and the percentage of deaths and sickness at this time is very much higher.

Dr. H. A. Lorentz: I was much interested to hear Captain Rawling's lecture to-night. I am perhaps the one that can best understand all the miseries of this expedition, because I experienced on my second expedition the same conditions. But as we see the results of this expedition, this map, the splendid series of photographs, the discovery of a Pygmy race, well, I consider it is my duty to bring my homage to those brave men who have so far succeeded. There are attractions in New Guinea which so influence one, that the desire is strong to visit this land again - at least that is my experience, and $I$ hope that another British expedition may be formed, and I am sure that they will this time reach the Snow mountains, having profited by the experience they gained on this expedition.

Mr. W. R. OaILvIE-Grant : I think there is very little left for me to say after all we have heard, except to offer my most sincere congratulations to the members of our expedition on the splendid final success they have achieved. In the other room you will see a small selection of the mammals, birds, and ethnological objects which have been collected by the expedition, and I think when you look at the beautiful birds you will allow that they are quite as interesting as the natives which you have been shown-and possibly even more beautiful.

Dr. H. O. Forbes : I shall only detain the meeting a few minutes, but I should like, in response to your request, sir, to offer my sincere congratulations to Captain Rawling on the splendid work he has accomplished, the account of which we have just heard. With the exception of the members of the expedition, there are few perhaps in this room who can sympathize with him as I can in the extraordinary difficulties he had to meet. It was my aspiration to reach the top of Mount Owen Stanley, just as it has been Captain Rawling's to reach the top of the Charles Louis range. I experienced the same knife-edged ranges and deep torrent-swept gorges that seem to bar the flanks of the culminating peaks which rise in that long range of mountains that extends from the north of New Guinea down through Australia, and continues across the Antarctic continent, and through the Andes of South America. The same difficulties he had, I experienced with the natives both of the country and of the Indian Archipelago, who were my carriers, and I also had similar troubles with regard to beri-beri. It may be worth mentioning, perhaps, that some of the Malays, those especially addicted to the opium habit, in my camp were so ill as to be quite unable to walk, and as it was impossible for me to transport them to the coast, and equally impossible to leave them in the midst of people of a different race, I had great 
anxiety as to their fate. I attempted to treat the disease with very little previous knowledge of it, by administering to these men internally the only medicament in my medicine chest I could think of likely to be of benefit, tincture of iodine, in very small and dilute doses at first, but increasing to about one minim daily, and I am glad to say, after several months, all these men who were at one time incapacitated from walking were able to reach the coast on their own feet. I should have liked to offer a few remarks on some of the very interesting observations made by Captain Rawling, such as the customs of the natives, the ethnological position of the "pygmies," and on the geological structure of the precipitous wall described by him ; but at this very late hour I will only congratulate Captain Rawling that he has brought his company and himself safe back to civilization, despite the physical dangers they encountered, and the incessant disease they had to fight against.

Dr. Mackintosh BeLL : First of all, may I say how very much I have enjoyed Captain Rawling's most interesting lecture ? We have all realized, I am sure, what great hardships he has undergone. I for one appreciate what he has had to overcome, because I have just recently returned from New Caledonia, which presents somewhat similar though less serious difficulties. New Caledonia bears a marked resemblance to New Guinea in many respects. The physiographical features of the latter, if we can judge from the photographs which we have just seen, are very similar to those of New Caledonia. In the two islands there is apparently a coastal plain, while farther inland there are ridges of low hills deeply desiccated, and so much covered with vegetation that the rocks are almost nowhere visible. Beyond these lies in each case a mountainous hinterland. I should like to know if the mountains which Captain Rawling describes as showing a flat crest-line represent a desiccated plateau, that is an elevated surface of horizontal strata or a desiccated peneplain, that is a former base-level of erosion formed near sea-level and afterwards elevated. May I congratulate Captain Rawling on his most interesting paper ? and I hope when his results are published he will give us some geological data as well as anthropological and geographical material. I should like to know if, in the mountains, the strata lie flat or stand at various angles?

Captain RAwLING : The strata of the rocks forming the great central range rise at an angle of $25^{\circ}$ from the north to the south. It appears probable that two contrary earth-movements are taking place; the range itself being slowly forced upwards, while the land from the foot of the precipice to the sea continues to sink.

I have been asked as to whether the Mimika natives are cannibals. In our opinion they are not, for no signs of cannibalistic practices were seen by us. Several of the men had their front teeth filed to a point, a custom believed by many to be a proof of cannibalism, but our opinion is that in this district the filing, or rather chipping of the teeth, is only undertaken as a facial adornment.

Sir THomas HoLdrch : I think we may, in common with the last speakers, congratulate Captain Rawling on having brought a most interesting expedition to a safe conclusion. I have now only to ask you to express your thanks to him in the usual way for his very able lecture. 